\title{
"Zhivaia Starina" in the year 2010
}

\author{
Dmitry Nikolaev \\ Centre for Typological and Semiotic Folklore Studies \\ Russian State University for the Humanities \\ Moscow, Russia
}

In the year 2010 "Zhivaya Starina" continued to focus on Slavic folklore and also made occasional forays into folklore traditions of different areas of the world. It also published articles dealing with theoretical problems. All of the articles were in Russian.

Volume 1 (65) 2010 opens with a large section on what can be called "naive" folkloristics, that is folklore collecting by amateurs. The first article in this section is by O. R. Nikolaev and is entitled "Naive folkloristics: Types, forms, functions." It provides a definition of the phenomenon and distinguishes several types of naive folkloristic discourse. According to O. R. Nikolaev, naive folkloristics is characterized by the array of texts produced by the bearers of a traditional worldview who try to preserve and systematize the lore of their community. The stimulus for such an activity may come from outside. One example is the questionnaires distributed by some official scientific body. Such a situation is typified by instances of nonprofessional field work. When outside stimulus is lacking we are dealing with more authentic forms of popular folkloristic discourse. The most important instances of the latter kind are text collections, such as those which include songs, aphorisms, recipes, charms, and so forth, and autobiographies, which often contain minute descriptions of various rituals and may include other traditional lore. The remaining articles of this section present several examples of naive folkloristic work. Folklore materials published in Olonets Province newspapers from the 19th to the beginning of the 20th centuries are reviewed by S. V. Fedorova. A collection of chastushkas (a rough equivalent of limericks) assembled by I. I. Timin in the 1920s-30s is presented by K. E. Korepova. A review of the work of the naive ethnographer and folklorist T. V. Azhgibkov by A. $\mathrm{N}$. Vlasov and M. V. Akhmetova is followed by some excerpts from his archive. The section ends with a naive dictionary of the local dialect compiled by A. A. D'iachenko who lived in Kargopol Oblast. It was prepared for publication by A. B. Moroz. There is also a small collection of scary stories recorded in different summer camps by a schoolgirl named V. Rostova. It was prepared for publication by T. G. Vaulina and 


\section{N. M. Iakubova.}

The second section of Volume 1 bears the title "The Cemetery in traditional culture". It contains articles on modern burial practices. These include "Modern cemeteries in the Ulianovsk Oblast" by A. M. Carvalheiro and M. G. Matlin and an article on behavior codes connected with cemeteries contributed by V. E. Dobrovol'skaia. There is an article on inscriptions on modern tomb-stones by D. V. Gromov, as well as an archaeological description of the burial of archbishop Nikifor, the prior of Danilov Monastery in Moscow who died in 1800. The latter was written by L. A. Beliaev. The section concludes with an overview of the history and modern manifestations of the cult of the sepulchre of Victor Noir in the Père-Lachaise cemetry in Paris by M. A. Griva.

The last thematic section of the volume is devoted to Old Believers, their traditions and the process of their adaptation to modern realities. The articles in this section include a contribution on Old Believers of Samodurovka in Saratov Oblast by N. V. Sveshnikova and T. N. Medvedeva. There are articles on Russian Old Believers in Alaska by R. Morris and T. B. Morris and on the Old Believers of the Belgorod Oblast by L. V. Khir'ianova. O. B. Khristoforova contributes an article on Perm Oblast and Udmurtia Old Believers and their views of illnesses.

Volume 2 (66) begins with an overview of the activities of the State Republican Center for Russian Folklore (http://www.centrfolk.ru), the organization which publishes "Zhivaia Starina" The year 2010 marked its 20th anniversary. This overview is followed by responses to the questionnaire distributed by "Zhivaia Starina" to the participants of the Second All-Russian Folklore Congress held outside Moscow in 2010. The questions asked included: "What did you gain by participating in the Congress?" and "Which discussions seemed the most interesting and memorable to you?" This section is followed by recommendations formulated during one of the plenary meetings of the Congress.

The thematic sections in volume 2 are "The Great Patriotic War in folklore" and "Numbers in folklore". The first section includes a sample of World War II period chastushkas from Tver Oblast written by E. M. Beletskaia. There is an overview of narratives covering the pre-war period when, according to a popular belief, various signs presaging a war appeared. There is a survey of popular beliefs concerning prohibitions and injunctions that were supposed to help a man return from the war alive written by V. E. Dobrovolskaia. Three folk songs of the war period are published by V. V. Zaporozhets. There is a sample of war-time narratives from the Kaluga Oblast containing popular folkloric motifs 
presented by L. F. Mironikhina. An excerpt from the autobiography of N. D. Dorzhiev covering his participation in the war is published by N. N. Vokhman and S. Iu. Nekliudov. An example of naive poetry, a ballad in praise of the armoured train "Il'ia Muromets" composed in 1965 by the railroad worker G. Shugaev is published by M. V. Akhmetova.

The second section features analytical contributions: "Numbers in the popular magic of Southern Slavs" by L. Radenković, "'Odin' ['one'] and 'pervyj' ['first'] in the traditional culture of Vladimir Oblast" by V. E. Dobrovolskaia, and "Three sixes, or 'Solomon the Wise's number"" by O. V. Belova.

The volume also includes an overview of the journal "Art" published in the Komi Republic and covering local folklore and ethnography. Several articles from "Art's" archive are reproduced. These include: "Legends about Stephen of Perm in Komi folklore" by P. F. Limerov, "The rektas'yöm ritual in the Komi magic" by A. V. Paniukov, and "The Sorcerer-eretnik in the magic connected with Maundy Thursday among the Komi" by L. S. Lobanova.

Volume 3 (67) contains a sample of contributions to the Second All-Russian Folkloristic Congress presented in the form of articles. These are "On the reconstruction of Russian [musical instrument] trenzel" 'by O. V. Gordienko, a paper on the interaction of Russian and Ukrainian song traditions in Siberia by N. N. Vokhman. "Youth subcultures and their mythologization in contemporary society" is D. V. Gromov's contribution. An analysis of humorous adjacency pairs in Russian popular discourse is written by $\mathrm{O}$. Iu. Boitsova.

The next section of the volume is devoted to Kazakh folklore. It contains the following articles: "Kazakh legends recorded in Russian" by A. D. Tsvetkova. "The tradition of blessings among the Kazakhs" is written G. A. Meirmanova. "Lullabies of the Chats of the Ob' region" is by N. S. Kapitsyna. A paper on the problem of classification of traditional musical instruments of the Turkic peoples of Siberia is by N. M. Kondrat'eva and "Contemporary folklore of Northern Bashkirs" is by G. R. Khushianova.

The subsequent section bears the title "The house in traditional culture". It includes "The chimney in the beliefs and rituals of Polesie" by M. A. Andriunina. "Adobe buildings in Verkhnekhavskii Region of Voronezh Oblast" is by T. F. Pukhova. An article on the so called "Aleshka's House" - an old peasant house in Arkhangelsk Oblast adorned with rich naive murals is by Iu. G. Terekhova. A description of the celebration of the 30th anniversary of a house in Mohyliv-Podilskyi 
by M. V. Akhmetova concludes the section.

The last thematic section in the volume deals with the folklore tradition of Kostroma Oblast. It includes an article on the role of beer in various calendar festivities in Vetluga Region by T. V. Kiriushina and a series of ethnolinguistic notes on the dialect of Pavinsii Region. Among these are a piece on demonological vocabulary N. A. Sinitsa, and an article on the terms dvoezuby (two-teethed), dvoeglazyi (two eyed) and similiar terms by E. V. Shabalina. Also included is an article on the terms merzloglaz (cold-eyed) and merzloguz (cold-bottomed) as these two terms are related to frost. This piece is by O. V. Atroshenko. An article on lexemes and phraseological units connected with various family rites is by O. M. Gareeva and L. A. Feoktistova.

Volume 4 (68) begins with a section on legends and etiological tales in various traditions. A. A. Panchenko traces the history of the AT 2401 tale type (Children play at hog-killing, type 1343 in ATU). O. V. Belova and A. B. Moroz analyse legends connected with the St Nicholas Cathedral in Chernivtsi. Iu. V. Klochkova describes the mythology surrounding the so called Kharitonov House in Ekaterinburg. Some new and archival field recordings are published. These include contemporary tales about the relics of Seraphim of Sarov written by Iu. M. Shevarenkova. There are excerpts from the 19th-century manuscript collection "Fairy tales, legends and so forth of Orlov County, Viatka Province recorded by N. Dobrotvorskii". These are published by V. A. Pozdeev. A sample of etiological tales recorded at the end of the 20th the beginning of the 21st century in Moscow and Krasnodar Region is presented by V. V. Zaporozhets.

The next section is devoted to the popular culture of Belarus. It includes the following articles: "Belorussian ethnolinguistic atlas: History, archive, results, and perspectives" by N. P. Antropov. "Even or odd?" by S. M. Tolstaia. A paper on magical formulas used to steal milk is by L. N. Vinogradova. "Folk prose in the contemporary Belorussian countryside" is by E. M. Boganeva. "Holy springs in Belarus Dvina Region" is contributed V. A. Lobach. "On men's and women's horns" is by T. V. Volodina. G. I Lopatin contributes "Legends of the cat's and dog's share".

The last thematic section in this issue bears the title "Beliefs and customs". It includes contributions on offerings to the dead among the Romanians by A. Olteanu. There is an article on the veneration of icons placed on the Krivankovo Well in Tiumen Oblast by E. E. Ermakova. Mardi Gras festivities in Belgorod Oblast are describe by N. V. 


\section{REPORTS}

Solodovnikova.

The volume also includes an overview of the journal "Antropologicheskii Forum" ("Anthropological Forum") published by Peter the Great Museum of Anthropology and Ethnography (the Kunstkamera) and an article from its archive: "Laundry rinsing: Symbolical order of daily practice" by S. B. Adon'eva.

Articles from "Zhivaia Starina" can be purchased in pdf format at: http://elibrary.ru/issues.asp?id=8670\&selid $=535233$ 